\title{
傍突起部内頝動脈瘤の発育方向とコイル塞栓術の治療結果
}

\author{
伊藤 英道 ${ }^{1)}$, 森嶋 啓之 ${ }^{2)}$, 小野寺 英孝 ${ }^{1)}$, 和久井 大輔 ${ }^{2)}$, 田中 雄一郎 ${ }^{1)}$, 橋本 卓雄 ${ }^{1)}$ \\ 1）聖マリアンナ医科大学脳神経外科，2）聖マリアンナ医科大学横浜市西部病院脳神経外科
}

\section{Treatment Results of Endovascular Surgery based on Projection of Paraclinoid Internal Carotid Artery Aneurysms}

\author{
Hidemichi Ito M.D. ${ }^{1)}$, Hiroyuki Morishima M.D. ${ }^{2)}$, Hidetaka Onodera M.D. ${ }^{1)}$, Daisuke Wakui M.D. ${ }^{2)}$, \\ Yuichiro Tanaka M.D. ${ }^{1)}$, and Takuo Hashimoto M.D. ${ }^{1)}$ \\ 1) Department of Neurosurgery, St. Marianna University School of Medicine, 2) Department of Neurosurgery, St. Marianna Univer- \\ sity School of Medicine, Yokohama City Seibu Hospital
}

Object : In order to predict the technical difficulties of coil embolization for paraclinoid aneurysms (PC-an), we retrospectively analized our clinical experience.

Method: We analyzed 34 patients with $35 \mathrm{PC}$-an treated with endovascular techniques between 2001 and 2010. These aneurysms were classified into 4 groups on the basis of their projections visualized on angiograms as follows: ventral, 17; medial, 7; dorsal, 8 and lateral, 3. The size of the aneurysms and the angle of carotid siphon were measured on angiograms for each group. The levels of those aneurysm necks were classified as supraclinoid, clinoid and infraclinoid according to their relation to the anterior clinoid process. Angiographic outcome, volume embolization ratio (VER), number of microcatheters and microguidewires used and duration of endovascular procedure were evaluated for each group. Clinical outcomes were assessed using the Glasgow Outcome Scale (GOS).

Result: The mean size of the aneurysms in the ventral, medial, dorsal and lateral groups was 4.1, 5.6, 6.7 and $8.4 \mathrm{~mm}$, respectively. The mean angle of carotid siphon was more acute in the dorsal and lateral groups. The neck level was supraclinoid in 10, clinoid in 14 and infraclinoid in 11. The percentage of dorsal and lateral groups was larger in the supraclinoid level. Endovascular treatment was successfully performed in $91.4 \%$ cases with treatment complications including 3 ischemic events. The number of patients with clinical outcomes classified according to the GOS was as follows : good recovery, 31 ; moderately disabled, 2 ; severely disabled, 1 ; vegetative state, 0 and dead, 1. Complete obliteration was achieved in $70.6 \%, 57.1 \%, 32.5 \%$ and $0 \%$ patients in the ventral, medial, dorsal and lateral groups, respectively, and the corresponding VER was 37.6\%, 32.3\%, 24.8\% and $16.4 \%$. The number of microcatheters and microguidewires used was higher in the dorsal and lateral groups than that used in the other 2 groups. The duration of the procedures was also longer in the dorsal and lateral groups.

Conclusion: Endovascular treatment is a safe and effective therapeutic alternative for $\mathrm{PC}$-an. However, in dorsal and lateral $\mathrm{PC}-$ an, this treatment entails additional difficulties of handling microcatheters and microguidewires because of their anatomical specificity. Therefore, endovascular treatment for these aneurysms is occasionally associated with lower rates of complete obliteration and lower VER than those of ventral and medial PC-an.

(Received July 11, 2011; accepted October 31, 2011)

Key words : coil embolization, endovascular treatment, internal carotid artery, paraclinoid aneurysm, volume embolization ratio.

Jpn J Neurosurg（Tokyo）21:481-488, 2012

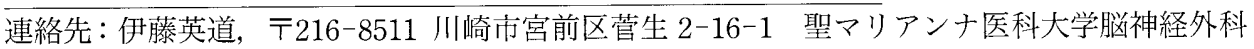

Address reprint requests to: Hidemichi Ito, M. D., Department of Neurosurgery, St. Marianna University School of Medicine, 2-16-1

Sugao, Miyamae-ku, Kawasaki-shi, Kanagawa 216-8511, Japan 


\section{はじめに}

傍突起部内䅡動脈溜（paraclinoid aneurysm：PC-an） は，他部位の動脈溜と比較して開頭術によるクリッピン グがより困難である。一方，血管内治療によるコイル塞 栓術は比較的低侵襲であり，コイル自体の進化や併用す る種々の器材や手技の発達により, PC-anに対する治療 成績も良好になった ${ }^{11) 21)}$. PC-an は血管分岐や動脈溜の 発育方向や高位によりさまざまに分類され(2)36)233，報告

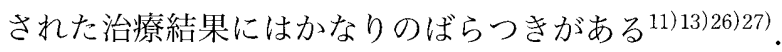
これまでに発育方向に着目した詳細な検討はない.今回, われわれは $\mathrm{PC}-$ an 自験例を発育方向で 4 群に分類し, 動脈溜や内頝動脈（internal carotid artery：ICA）の解剖 学的な特徴を分析して, 治療成績や治療難易度との関連 を比較検討した。

\section{対象および方法}

対象は 2001 年 4 月 2010 年 3 月の間に当科で留内 塞栓術を行った $\mathrm{PC}-\mathrm{an} 34$ 例, 35 病変である. 患者は平 均 54（28〜81）歳, 男性 5 例, 女性 29 例であった。動 脈瘤の部位は ICAの $\mathrm{C} 2$ から C 3 に動脈瘤頝部を有する ものとした，大きさは平均 $5.5 \pm 2.4(2.5 \sim 12.0) \mathrm{mm}$ で あった。 ワイドネックの定義は, dome/neck 比が 2 以下 のものとし，23 例（65.7\%）に認められた。また，発症
形式は未破裂（すべて無症候性）29 例，破裂 5 例（World Federation Neurosurgical Scale; WFNS grade I $: 2$ 例, II $: 2$ 例, IV $: 1$ 例) であった。

これらの PC-an を脳血管撮影上の正面像, 側面像をも とに, ICA からの発育方向別に 4 群に分類した。 そ扎ぞ れ, 腹側群 (正面像で内側, 側面像で後方, あるいは下 方へ projection), 内側群 (正面像で内側, 側面像で前方, あるいは上方へ), 背側群 (正面像で外側, 側面像で前 方, あるいは上方へ), 外側群 (正面像で外側, 側面像で 後方，あるいは下方へ）である（Fig. 1).

さらに，母血管であるICAのサイホンの屈曲角度と動 脈溜頚部の高位について脳血管撮影側面像で測定した

(Fig. 2).サイホンの屈曲角度の測定方法は, (1)サイホン の内側縁から水平線を引き, 線上に ICA の中点（A）を 決める。(2)内側縁に沿って垂線を引き，上下に存在する ICA の supraclinoidal portion (B) $と$ cavernous portion (C) それぞれの中心点を垂線上に決める. (3)以上の 3 点の形 成する角度をサイホンの分岐角度とした，また，高位に 関しては動脈瘤䅡部の位置を, 前床突起を基準に supraclinoidal level, clinoidal level, infraclinoidal level の 3 レ ベルに区分した ${ }^{29)}$.

治療内容は, 破裂例, 未破裂例共に同一術者で全身麻 酥下に施行し，全例で右大腿動脈アプローチを用いた。 80〜100 単位 $/ \mathrm{kg}$ のヘパリンを全身投与して, activated clotting time を 200〜250 秒に維持して行った. 6 Fr ガ
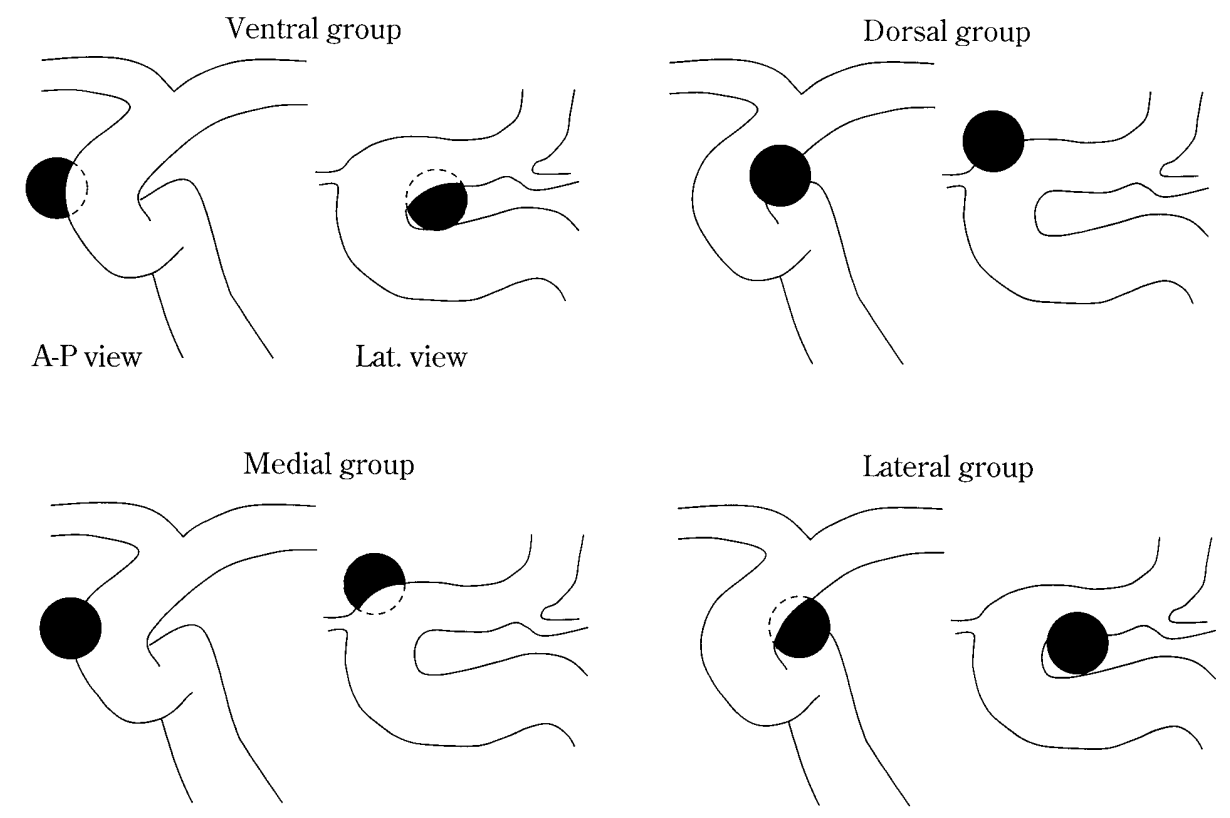

Fig. 1 Group classification according to the aneurysm's projection (case: left $\mathrm{PC}-$ an.) 


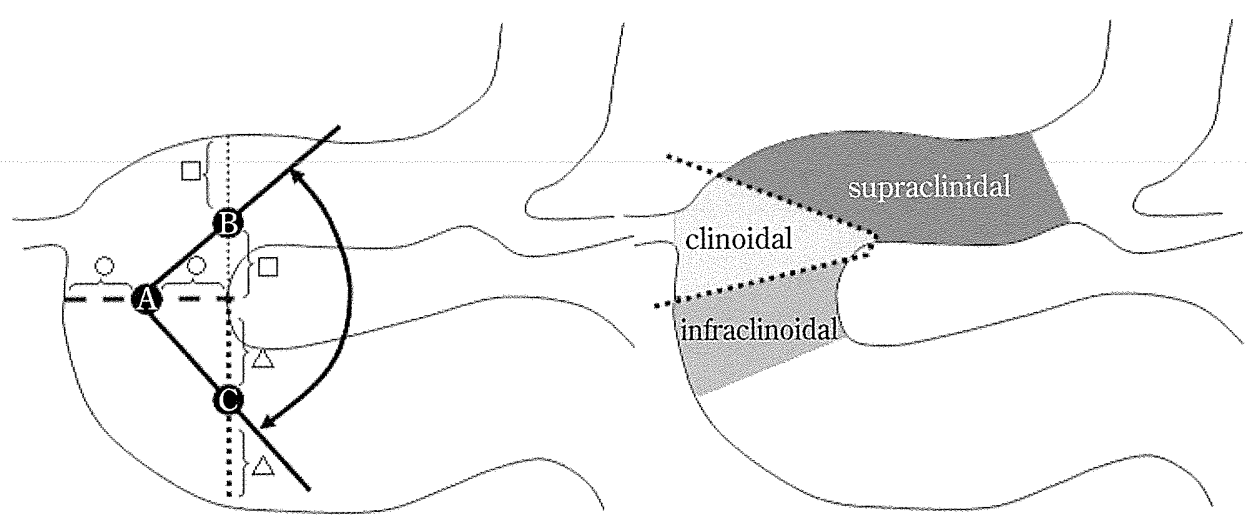

Fig. 2 Left: Illustrated lateral angiogram demonstrating the method for measuring the angle of carotid siphon

(1)First, determining the midpoints of the following 3 lines: the horizontal line which represents the clinoidal portion of the ICA (midpoint=A), and the vertical lines that represent the supraclinoidal $($ midpoint $=\mathrm{B}$ ) and cavernous (midpoint $=\mathrm{C}$ ) portions of the ICA.

(2) Measuring the angle between a line $\mathrm{A}-\mathrm{B}$ and a line $\mathrm{A}-\mathrm{C}$.

Right: Level of aneurysm neck

PC-an were categorized as supraclinoid, clinoid and infraclinoid based on their relations to the anterior clinoid process as they appear on lateral angiograms of the ICA. A dotted lines indicate the configuration of anterior clinoid process.

イディングカテーテルを患側 ICA 錐体部に留置し，マイ クロカテーテル (Excelsior SL-10: Boston Scientific, Fremont, CA, USA) とマイクロガイドワイヤー（TRANSEND : Boston Scientific, Fremont, CA, USA), ネック リモデリング用バルーンカテーテル (HyperGlide, HyperForm: Micro Therapeutics, Irvine, CA, USA. その他) を同軸に挿入した。マイクロカテーテルはサイホンの形 状，および ICA から動脈瘤への分岐角度を考慮して先端 形状を選択し, 主に $45^{\circ}$ と $90^{\circ}$ の preshaped type を使用 した.また, 瘤内への誘導が困難な場合はマイクロカテー テルを変更した。コイルは主に Guglielmi detachable coil (GDC : Boston Scientific, Fremont, CA, USA) を用い たが, ED coil (カネカメディックス, 大阪) や Cerecyte Ultipaq (Micrus Endovascular, Sunnyvale, CA, USA) を組み合わせ, 動脈瘤の径, 形態, 塞栓の進展に応じて 適切なものを選択した。また，必要に応じてネックリモ デリング法を利用した ${ }^{20)}$.

術後にヘパリンの中和は行わず，クロピドグレル単剤 による抗血小板療法を 3 力月間継続することを原則と している。

臨床評価として, 術後血管撮影上の塞栓効果（complete obliteration: $\mathrm{CO}$, neck remnant: NR, body filling: $\mathrm{BF}$ ), 塞栓率 (コイル体積/動脈瘤体積), 臨床転帰 (Glas- gow outcome scale: GOS, good recovery: GR, moderate disability: MD, severe disability: SD, vegetative status: VS， death：D）を検討した。 また，術中に使用したマイ クロカテーテルとマイクロガイドワイヤーの総数, 手術 時間より治療難易度を比較した。検定には Mann-WhitneyのU検定を利用した。

\section{結 果}

PC-an を 4 方向に分類すると, 腹側群 17 例 (48.6\%), 内側群 7 例 $(20.0 \%)$, 背側群 8 例 $(22.8 \%)$, 外側群 3 例 $(8.6 \%)$ であった。

\section{1 解剖学的特徵}

動脈瘤の大きさはそれぞれ，4.1 $\pm 0.8(2.5 〜 5.5) \mathrm{mm}$, $5.6 \pm 1.8(3.5 \sim 8.0) \mathrm{mm}, 6.7 \pm 1.6(5.0 \sim 9.0) \mathrm{mm}, 8.4 \pm$ $4.5(4.0$ 12.0） $\mathrm{mm}$ であった. ワイドネック例の占める 割合は， 12 例 $(70.6 \%), 7$ 例 $(85.7 \%), 3$ 例 $(37.5 \%)$, 1 例 $(33.3 \%)$ で, 腹側群と内側群に多かった. ICA サ イホンの屈曲角度は $100.7 \pm 9.7^{\circ}, 99.2 \pm 12.8^{\circ}, 91.3 \pm$ $8.4^{\circ}, 95.0 \pm 10.0^{\circ}$ であった（Table 1). 腹側群, 内側群と 比べ, 背側群と外側群の屈曲角度は小さく, ICA サイホン が急峻なカーブを形成していた。高位別にみると, supra- 
Table 1 Anatomic characteristics in each group

\begin{tabular}{|c|c|c|c|c|c|c|}
\hline Group & Number & Size, $\mathrm{mm}$ & & Wide neck & & Angle of Carotid Siphon \\
\hline Ventral & 17 & $4.1 \pm 0.8$ & & $12(70.6 \%)$ & & $100.7 \pm 9.7^{\circ}$ \\
\hline Medial & 7 & $5.6 \pm 1.8$ & & $7(85.7 \%)\}$ & & $99.2 \pm 12.8^{\circ}$ \\
\hline Dorsal & 8 & $6.7 \pm 1.6$ & $*$ & $3(37.5 \%)$ & $* *$ & $91.3 \pm 8.4^{\circ}$ \\
\hline Lateral & 3 & $8.4 \pm 4.5$ & & $1(33.3 \%)\}$ & & $95.0 \pm 10.0^{\circ}$ \\
\hline
\end{tabular}

Level of aneurysm neck Incidence of each group

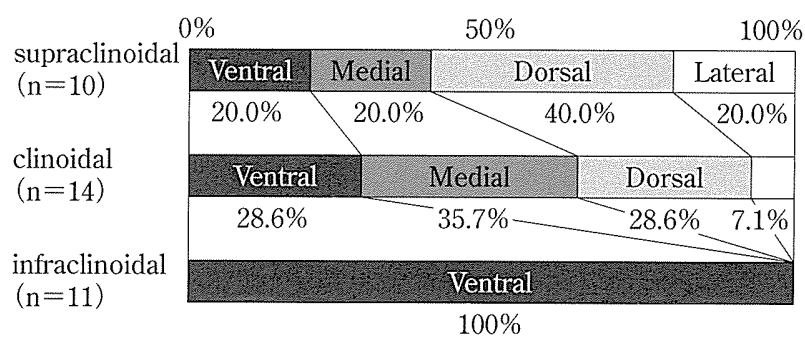

Fig. 3 Level of aneurysm neck and incidence of each group

Bar graph showing the incidence of ventral, medial, dorsal and lateral aneurysms at supraclinoidal (upper), clinoidal (center), and infraclinoidal (lower) levels.

clinoidal level 10 例 (28.6\%), clinoidal level 14 例 $(40.0 \%)$, infraclinoidal level 11 例 $(31.4 \%)$ であり，大 きさはそれぞれ, $8.7 \pm 2.5 \mathrm{~mm}, 4.8 \pm 1.1 \mathrm{~mm}, 4.1 \pm 0.9 \mathrm{~mm}$ であった，高位になるにしたがって背側群，外側群の割 合が増加し，動脈瘤が大きくなる傾向があった。また， infraclinoidal level は全例が腹側群であった（Fig. 3).

\section{2 治療結果}

35 例中 32 例 $(91.4 \%)$ で治療を完遂した。19 例 (54.3\%) にネックリモデリング法を適用した。4 群別で は腹側群に 10 例 $(58.8 \%)$ ，内側群に 5 例 $(71.4 \%)$ ，背 側群に 4 例 $(50.9 \%)$ に適用し，外側群には使わなかっ た．完遂できなかった 3 例 (8.6\%) はすべてワイドネッ クであり，血管の屈曲や蛇行によりネックリモデリング のためのバルーンカテーテルが誘導できなかった. simple technique にて瘤内塞栓を試みたが，コイルは母血管 へ逸脱し, 理想的な framing が形成できないために断念 した。後日 3 例のうち 2 例で再治療を行った。ガイディ ングシースを用いてバックアップを強化したことでバ ルーンカテーテルの誘導が可能となり，ネックリモデリ ング法を用いて塞栓術を完遂した。もう 1 例は経過観察 中である.
血管撮影上の治療効果と塞栓率を Table 2, Fig. 4 に示 す. 完全閉塞（CO）の割合は，それぞれ 70.6\%，57.1\%， $37.5 \%, 0 \%$ でり, 腹側群と内側群は良好な治療結果が 得られたものの, 背側群と外側群でやや劣った。 塞栓率 に関しても腹側群と内側群に比べ, 背側群と外側群にお いて有意に低かった。手技に関連する合併症は 3 例 （8.6\%：2 例は末破裂例）に生じ，すべて虚血性合併症で あった. 3 例ともネックリモデリング法は利用していな い. 出血性合併症は認められなかった。臨床転帰は GR： 31 例 (88.6\%), MD : 2 例 (5.7\%), SD : 1 例 (2.9\%), VS：0，D：1例 (2.9\%) であった. MDの 1 例は破裂例 で，治療経過は良好であったが高齢のため廃用性障害が 生じた。もう 1 例は未破裂例で, 脳血栓症による永続的 な右片麻㽻を生じた. SD の 1 例は grade IVで, 死亡した 1 例は未治療の対側内頚動脈一前脈絡叢動脈瘤の破裂よ るものだった。

フォローアップは MRA で行った。背側型の 1 例に術 後 1 カ月で coil compaction を認め, 追加塞栓術を行っ た. 1 年後の MRA 評価は 32 例で悪化例は認めなかつ た.

\section{3 治療難易度}

各群における使用したマイクロカテーテルおよびマイ クロガイドワイヤーの総数，治療時間を Fig. 5 に示す. 腹側群と内側群に比べると，背側群と外側群はマイクロ カテーテルおよびマイクロガイドワイヤーの使用総数が 多く，コイル塞栓術に要した時間も長かった。

\section{考 察}

PC-an は, 動脈瘤頝部を distal dural ring から後交通動 脈分岐部までに有するものと定義され，全頭蓋内動脈瘤 の 1.5〜8.0\%を占める6)7)9)11)16)27). 最近では MRA や脳 ドックの普及により，無症候性動脈溜が検出される頻度 が増加しており，未破裂動脈瘤のうち 11〜20\%を占める との報告もある6)11)27)。治療法に関しては他部位の脳動 脈瘤と同様に開頭クリッピング術が行われてきた。根治 
Table 2 Angiographical results of coil embolization

\begin{tabular}{|c|c|c|c|c|c|}
\hline \multirow{2}{*}{ Group } & \multicolumn{4}{|c|}{ Degree of coil embolization } & \multirow{2}{*}{$\begin{array}{l}\text { Mean } \\
\text { VER }\end{array}$} \\
\hline & $\mathrm{CO}$ & NR & $\mathrm{BF}$ & $\mathrm{AT}$ & \\
\hline Ventral & $12(70.6 \%)$ & $3(17.6 \%)$ & $1(5.9 \%)$ & $1(5.9 \%)$ & 37.6 \\
\hline Medial & $4(57.1 \%)$ & $2(28.6 \%)$ & $0(0)$ & $1(14.3 \%)$ & $32.3\}$ \\
\hline Dorsal & $3(37.5 \%)$ & $5(62.5 \%)$ & $0(0)$ & $0(0)$ & 24.8 \\
\hline Lateral & $0(0)$ & $1(33.3 \%)$ & $1(33.3 \%)$ & $1(33.3 \%)$ & 16.4 \\
\hline
\end{tabular}

$\mathrm{CO}:$ Complete obliteration, NR : Neck remnant, BF : Body filling, AT : Attempt

Mean VER: Mean volume embolization ratio.

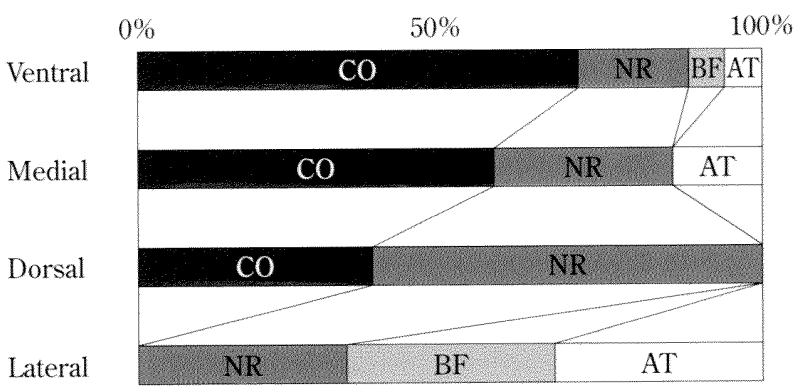

Fig. 4 Angiographical results of coil embolization in each group

性は高く，治療成績も概权良好であるが1428)，交全かつ 確実に行うためには，难部埕動脈確保や前床笑起削除， 視神経管開放，硬膜輸の切離などが必要で，手術侵襲が 高い ${ }^{1112)}$ 。 また，合作症として穿通枝障害や頭蓋底学削 除に伴う神経損儫や髄液漏，感染症などが報告されてお り，上り遠位の内頝動脈瘤に比較すると治療成績もやや 劣る ${ }^{6) 11}$ 。一方, 血管内手術は, 血管周囲の構造物は手

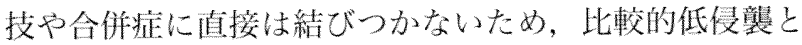
いえる。さらに近年はデバイスや画像診断技術の発達に より動脈瘤治療に適用される機会が著しく増加してお り，良好な監床転㷌が報告されている

PC-anには分䐈血管や動脈瘤の発育方向，高位に上る さまざまな分類法があり 2/376)23)，開䫓クリッピング術の 際にはそれぞれの動脈瘤に対応したアプローチ，クリッ プの選択など個々の症例に合わせた手術戦略と工夫学必 要とする。血管内手術に括いても同様で，カテーテルや コイルの選択，ネックリモデリング法20)やダブルカテー テル法けの適用などを検討する必要がある。

一般に PC-an は小型球形が多く,ワイドネックの割合 が $63 \%$ と多い ${ }^{26)}$. 発生部位に関しては, 眼動脈分䁌部觜

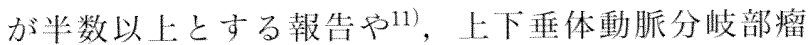
(superior hypophyseal artery aneurysm: SHA-an)が約 1 . 3 を占め最多とする報告などがあり ${ }^{26)}$ ，さまざまである。
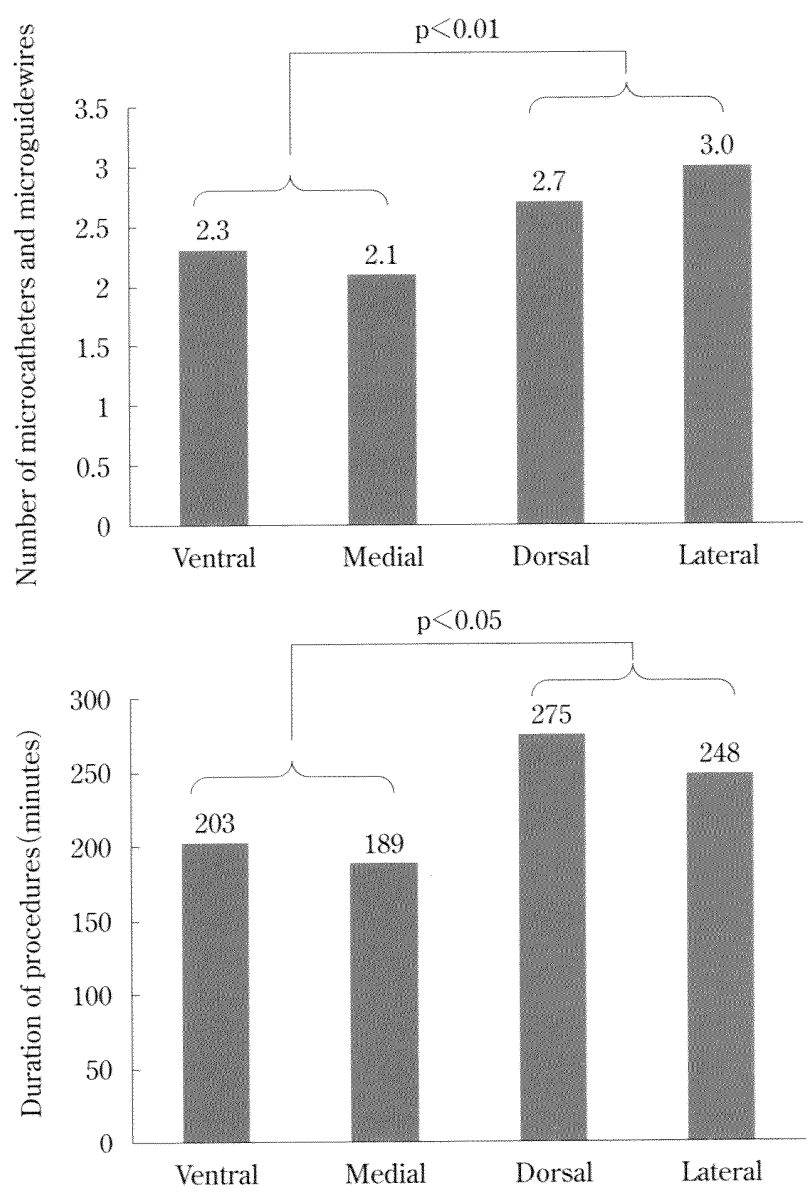

$\frac{A}{B}$

Fig. 5 Comparison of total number of used microcatheters and microguidewires (A), and duration of procedures (B)

The total number of microcatheters and microguidewires used were significantly higher in the dorsal and lateral groups than in the other 2 groups $(p<0.01)$; the duration of procedures in the dorsal and lateral groups were significantly longer ( $p$ $<0.05$ ). 
Tanaka $~^{299}$ は PC-an 85 例を手術所見をもとに分岐血管 別に分類し，解剖学的特徵を報告している。 そ机による と, PC-an の中で SHA-an は $47.1 \%$ と最多であり, 平均 $3.9 \mathrm{~mm}$ と最小, また大部分が infraclinoidal clinoidal level に存在し，内側下方への発育方向を示していた。 わ れわ机の結果では，腹側群が PC-anのうち $48.6 \%$ を占 め最多であった。他群と比較して小型であり, infraclinoidal〜 clinoidal level に88.2\%が存在している. 今回用いた 分類法では分岐血管を加味していないが，これらの結果 は腹側群が SHA-an の特徴を反映していると考元られ る。また，高位になるにしたがって瘤のサイズは大きく なった。これは，低位であれば動脈瘤が骨ないし硬膜， 視神経に囲まれて抢り，高位であれば周囲に発育を妨げ る構造物が少ないためと考光られる。PC-an とサイホン の屈曲角度に関する報告は少ない，開頭例の報告による と内䅡動脈前外側壁から発生した動脈瘤では内頚動脈 C 2 の走行が水平に近く, $\mathrm{C}_{3}$ からの屈曲が鋭的といわ れ(15)24)25)，わ机われが用いた分類法における背側群の所 見に類似していた。

治療結果に関しては，報告により出血発症例の割合が 異なるため一概に比較できないが，他の報告と比較する と PC-an 全体の結果は概子良好な成績といえ る ${ }^{1122) 26630)}$. 治療を完遂できなかった 3 例は，バルーン カテーテルの留置が不可能であった，大動脈や頝部顤動 脈が屈曲蛇行しており，バルーンカテーテルを末梢へ誘 導するとガイディングカテーテルが落下してしまった. ガイディングシースを用いるか，額部への直接穿刺を検 討すべきであった。

4 群別に検討すると, 背側群と外側群はワイドネック の割合が低いことから，一般的には上り高い塞栓効果が 期待されるが, 治療成績と塞栓率は背側群と外側群で低 い傾向があった。

さらにその 2 群はマイクロカテーテルとマイクロガ イドワイヤーの使用本数が多く, 治療時間も長かった. 以上より背側群と外側群に手技的難易度を高める解剖学 的要因があると考えら礼た。

PC-an は頭蓋内 ICA のうち最も近位に位置する動脈 瘤であるため，他の動脈瘤に比べてカテーテル操作が容 易であるという報告もあるが22)，PC-an はサイホン近傍 に存在するため, マイクロカテーテル誘導はやや難しい. Gurian $~^{10)}$ は，外向き（背側群や外側群）瘤へマイクロ カテーテルの誘導は困難と報告し，中原ら ${ }^{21)}$ は上方（背 側群や内側群）に向かう馏へのマイクロカテーテルの誘 導は比較的容易としており，術者によって意見はさまざ まである，最近のマイクロカテーテルの shaping に対す
る報告によると，上方突出型では $\mathrm{S}$ 字型，あるいは直型 を多く使用し，内方拉よび下方突出型では J 字型を用い るのが共通な認識である ${ }^{17) 18)}$.

また，PC-an へのマイクロカテーテルは distal neck に 沿って動脈瘤内に入ることが多く, マイクロカテーテル 先端を動脈瘤の中心に留置できないことも多い21)，その ため, 塞栓術の終盤でマイクロカテーテルが安定しない ために母血管内へコイルの逸脱をきたすことが多く，か つワイドネック例も多いことからネックリモデリング法 を要することが多い. Iihara ら ${ }^{13}$ は上方（背側群や内側 群）に向かう瘤への塞栓術は，マイクロカテーテルの安 定が得にくいため，症例によっては開頭クリッピング術 の方が安全，かつ完全な処置が可能となると報告してい る.

通常，ICA を正面から見ると C3から C2にかけて外側 上り内側へ向かって走行する。しかし，背側群と外側群 はICA に対して外側へ翻るように発育している。また， われわれの結果では, 背側群と外側群のサイホンは, 他 群と比べてより鋭角的な屈曲を形成していた。これらの 屈曲はマイクロカテーテルの蛇行とたわみを招く。そし てマイクロガイドワイヤーやコイル挿入時に，このたわ みが伸張すると，マイクロカテーテル先端が急激に移動 し，瘤穿孔を生じさせると考えら机る。また，これら背 側群と外側群の瘤は supraclinoidal type の多くを占めて おり，マイクロカテーテルはサイホンの屈曲による影響 を強く受けると考元られる。救因が，背側群と外 側群におけるマイクロカテーテルおよびマイクロガイド ワイヤーの操作性を劣化させ，塞栓率が低下したと考元 られる。結果的にマイクロカテーテルおよびマイクロガ イドワイヤーの使用本数が多くなり, 治療時間を長くし たと考える，その対応策として重要なことは，サイホン 部の屈曲から動脈瘤の発育方向や距離までを考慮した 3 次元的なマイクロカテーテルの shaping を形成するこ とであろう。一方で同群は他に比べ，より大きいために 塞栓率が低く算出さ机た可能性もある。

コイルの塞栓手技に関しては他部位の動脈瘤に対する 塞栓方法と同様である．留意点はマイクロカテーテルの 安定が得られにくいので，軟らかいコイルを選択すべき 点である．さらに，マイクロカテーテルの操作が困難な ことを考慮すると, GDC $360^{\circ}$ などの complex coil が有用 と考えられる。しかし helical coil と異なり，思わ始動き をして瘤壁にストレスをかける危険性や，マイクロカ テーテルが溜外へ晩脱する可能性があり注意を要する。 溜の大きさにもよるが，小型であれば helical coil を用い ることも1つの選択肢である。また，前述のとおりコイ 
ル逸脱予防のネックリモデリング法のみならず，バルー ンカテーテルはマイクロカテーテルの保持にも有用であ る. 特に背側群, 外側群ではマイクロカテーテルの蛇行 が強くなり不安定になるため，適切な shaping のみなら ずバルーンカテーテルの併用が効果的なコイリングにつ ながると考えら机る，最近では，コイル逸脱予防の動脈 瘤治療用のステントや ${ }^{5)}$ 19)，血流の整流効果によりコイ ルを用いずに動脈瘤の血栓化を促進するステントが開発 され ${ }^{8)}$ ，良好な成績が報告されている。この画期的な治 療法はわが国にも導入されつつあるが，現時点では適用 範囲に制限があるうえ，血栓形成やステント内狭窄など の問題も指摘されている5) 19)

\section{結 語}

PC-anに対する瘤内コイル塞栓術について，われわれ の経験と治療効果を検討した。 PC-anの治療結果は概ね 良好であり, 瘤内コイル塞栓術の有用性は高いと考える。 4 群に分類することで，解剖学的特徵に基づいた手技上 の留意点が導かれた．特に背側群と外側群は他と比べて 難治度が高く，より慎重な手技が要求される。

\section{文 献}

1）阿部友康，門田知倫，相原 寛，西尾晋作，河内正光， 松本祐蔵：破裂外向き paraclinoid carotid aneurysm の検 討。脳外誌 14:576-580, 2005.

2) Al-Rodhan NR, Piepgras DG, Sundt TM Jr: Transitional cavernous aneurysms of the internal carotid artery. Neurosurgery 33: 993-998, 1993.

3) Batjer HH, Kopitnik TA, Giller CA, Samson DS : Surgery for paraclinoidal carotid artery aneurysms. I Neurosurg 80:650-658, 1994.

4) Baxter BW, Rosso D, Lownie SP: Double microcatheter technique for detachable coil treatment of large, widenecked intracranial aneurysms. AJNR Am J Neuroradiol 19: 1176-1178, 1998.

5) Biondi A, Janardhan V, Katz JM, Salvaggio K, Riina HA, Gobin YP: Neuroform stent-assisted coil embolization of wide-neck intracranial aneurysms: strategies in stent deployment and midterm follow-up. Neurosurgery $\mathbf{6 1}$ : 460-469, 2007.

6) Day AL: Aneurysms of the ophthalmic segment: A clinical anatomical analysis. J Neurosurg 72:677-691, 1990.

7) Drake CG, Vanderlinden RG, AmacherAL: Carotid-ophthalmic aneurysm. J Neurosurg 29:24-31, 1968.

8) Fiorella D, Woo HH, Albuquerque FC, Nelson PK : Definitive reconstruction of circumferential, fusiform intracranial aneurysms with the pipeline embolization device. $\mathrm{Neu}$ rosurgery 62: 1115-1120, 2008.

9) Guidetti B, La Torre E: Management of carotid-ophthalmic aneurysms. J Neurosurg 42:438-442, 1975.

10) Gurian JH, Vinuela F, Guglielmi G, Gobin YP, Duckwiler GR: Endovascular embolization of superior hypophyseal artery aneurysms. Neurosurgery $39: 1150-1154,1996$.

11) Hoh BL, Carter BS, Budzik RF, Putman CM, Oglivy CS : Results after surgical and endovascular treatment of paraclinoid aneurysms by a combined neurovascular team. Neurosurgery 48, 78-90, 2001

12) Horiuchi $Y$, Tanaka Y, Kusano $Y$, Yako T, Sasaki T, Hongo $\mathrm{K}$ : Relationship between the ophthalmic artery and tha dural ring of the internal carotid artery. $J$ Neurosurg 111: 119-123, 2009.

13) Iihara K, Murao K, Sakai N, Shindo A, Sakai H, Higashi T, Kogure S, Takahashi J, Hayashi K, Ishibashi T, Nagata I: Unruptured paraclinoid aneurysm: A management strategy. J Neurosurg 99:241-247, 2003.

14）加藤㡺子，佐野公俊，入谷克已，神野哲夫，小倉祐子, 片田和廣：Juxta-dural ring aneurysm の分類と治療法. 脳 卒中の外科 $\mathbf{2 5}: 212-218,1997$.

15) Kinouchi H, Mizoi K, Nagamine Y, Yanagida N, Mikawa S, Suzuki A, Sasajima T, Yoshimoto T: Anterior paraclinoid aneurysms. J Neurosurg 96:1000-1005, 2002.

16) Kothandaram P, Dawson BH, Kruyt RC: Carotid-ophthalmic aneurysms: A study of 19 patients. J Neurosurg 34: 544-548, 1971.

17) Kwon BJ, Im SH, Park JC, Cho YD, Kang HS, Kim JE, Han MH : Shaping and Navigating Methods of Microcatheters for Endovascular Treatment of Paraclinoid Aneurysms. Neurosurgery $\quad 67: 34-40,2010$.

18）松丸祐司, 鶴田和太郎：Paraclinoid 瘤のコイル塞栓術. 脳 外速報 21：268-273，2011.

19) Mocco J, Snyder KV, Albuquerque FC, Bendok BR, Alan SB, Carpenter JS, Fiorella DJ, Hoh BL, Howington JU, Jankowitz BT, Liebman KM, Rai AT, Rodriguez-Mercado R, Siddiqui AH, Veznedaroglu E, Hopkins LN, Levy EII: Treatment of intracranial aneurysms with the Enterprise stent: A multicenter registry. $J$ Neurosurg 110:35-39, 2009.

20) Moret J, Cognard C, Weill A, Castaings L, Rey A: The "remodelling technique" in the treatment of wide neck intracranial aneurysms: Angiographic results and clinical follow up in 56 cases. Intervent Neuroradiol 3:21-35, 1997.

21）中原一郎，坂井信幸，永田 泉，西 正吾，秋山義典, 澤田元史，橋本信夫，菊池晴彦：内頝動脈硬膜輪近傍動 脈瘤に対する脳血管内手術。脳外誌 8：106-114，1999。

22）根本 繁，飯島 明，渡辺英寿，真柳佳昭，桐野高明： 内頝動脈硬膜輪近傍動脈溜の血管内治療，脳卒中の外 科 $27: 170-176,1999$.

23) Nutik SL: Ventral paraclinoid carotid artery aneurysms. $J$ Neurosurg 69:340-344, 1988 .

24) Nutik SL: Subclinoid aneurysms. J Neurosurg 98:731$736,2003$.

25）小野田恵介, 徳永浩司, 杉生憲志, 小野成紀, 伊達 勲： 前床突起下前外側壁に生じた内頝動脈瘤に対する直達手 術. No Shinkei Geka 34:267-272, 2006.

26) Park HK, Horowitz M, Jungreis C, Kassam A, Koebbe C, Genevro J, Dutton K, Purdy P: Endovascular treatment of paraclinoid aneurysms : experience with 73 patients. $\mathrm{Neu}$ rosurgery 53: 14-24, 2003.

27) Roy D, Raymond J, Bouthillier A, Bojanowski MW, Moumdjian R, LEsperance G: Endovascular treatment of ophthalmic segment aneurysms with Guglielmi detachable coils. AJNR Am J Neuroradiol 18: 1207-1215, 1997.

28）塩川芳昭，斉藤 勇：Carotid ring 近傍の脳動脈瘤の分類 
と治療. 脳卒中の外科 $25: 359-364,1997$.

29) Tanaka Y, Hongo K, Tada T, Nagashima H, Horiuchi T, Goto T, Koyama J, Kobayashi S: Radiometric analysis of paraclinoid artery aneurysms. J Neurosurg 96:649-653,
2002.

30) Thornton J, Aletich VA, Debrun GM, Alazzaz A, Misra M, Charbel F, Ausman JI: Endovascular treatment of paraclinoid aneurysms. Surg Neurol $\mathbf{5 4 : 2 8 8 - 2 9 9 , 2 0 0 0 .}$

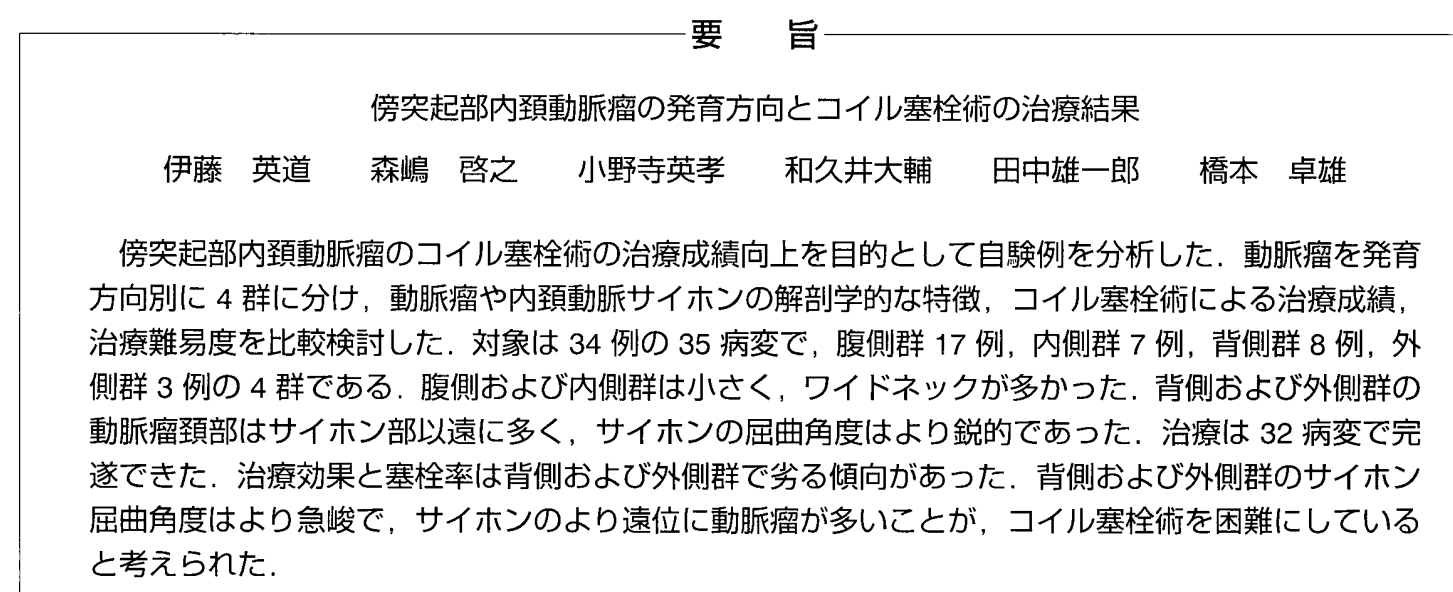

脳外誌 $21: 481-488,2012$

\section{Editorial Comment}

\section{傍突起部内䅡動脈旝に対するコイル塞栓術}

傍突起部内頝動脈瘤は外科的には前床突起の削除 を要し，近年では脳血管内治療の対象に比較的なり やすい部位の動脈瘤である。従来さまざまな分類が 提唱されてきたが，血管内治療では内頝動脈に対し て上向きの ophthalmic と下向きの superior hypophyseal artery の動脈瘤に分類することが多い. 筆者 らは動脈瘤の成長方向を 4 つに分類し, その治療難 易度を評価している。一般にこの部位の動脈瘤は内 頝動脈サイフォン部からの距離が近いためマイクロ カテーテルのシエイプの形状をどうするかによって 治療の成否が決まることが多く，市販のプレシェイ
東京慈恵会医科大学脳神経外科 村山雄一 プカテーテルではサイフォンの屈曲と動脈瘤の屈曲 にフィットせず, 不安定な塞栓になる可能性がある. さらに筆者らが経験しているように上下の二次元的 構造だけでなく，外側，あるいは内側に突出してい るため三次元的なカテーテルのシェイプが必要にな ることもまれではない，本論文では治療が完遂でき なかった症例を $8.6 \%$ 認めたが，三次元的なカテー テルのシェイプを工夫することや適切なガイディン グカテーテルの選択によりさらに良好な治療結果が 期待できるであろう。 